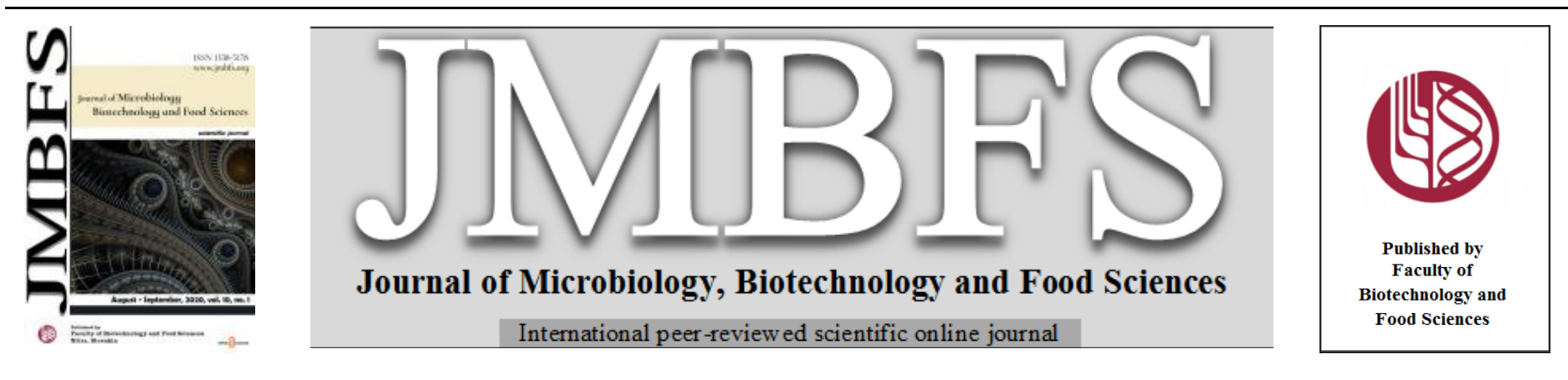

\title{
CONTENT of ORGANIC ACIDS in the CULTURAL MEDIUM of Bacillus subtilis IMV B-7023 at CULTIVATION WITH DIFFERENT SOURCES of the PHOSPHORUS NUTRIENT
}

\section{Iryna Skorochod ${ }^{\prime}{ }^{1}$, Alla Roy ${ }^{1}$, Ivan Kurdish ${ }^{1}$, Ulziijargal Erdenetsogt ${ }^{2}$}

Address(es): Iryna Skorochod,

${ }^{1}$ Department of Microbiological processes on solid surfaces, Zabolotny Institute of Microbiology and Virology, National Academy of Sciences of Ukraine; 154, Acad. Zabolotny St., Kyiv, MSP, D03680, Ukraine, Phone number: (+380-44) 526-90-11.

${ }^{2}$ National Technical University of Ukraine "Igor Sikorsky Kyiv Polytechnic Institute”; 37, Prosp. Peremohy, Kyiv, 03056, Ukraine.

*Corresponding author: aphalina.77@gmail.com

doi: 10.15414/jmbfs.2020.10.1.73-77

ARTICLE INFO

Received 18. 7. 2019

Revised 20. 3. 2020

Accepted 23. 3. 2020

Published 1. 8. 2020

Regular article open $\partial_{\text {ACCESS }}$

\begin{abstract}
The strain Bacillus subtilis IMV B-7023 is part of the complex bacterial preparation Azogran for crop production. This bacterium has the ability to increase the availability of phosphorus for plants through the synthesis of different organic acids. Using GS-MS, the qualitative and quantitative composition of organic acids in the culture medium of bacilli was investigated depending on the source of phosphorus nutrition in the nutrient medium. It was established that $B$. subtilis IMV B-7023 synthesizes the greatest amount of organic acids at cultivation in a glucose-mineral medium with calcium glycerophosphate after 24 hours. Among them: acetic, isobutyric, butyric, isovaleric, valeric, caproic, enanthic, caprylic, pelargonic. The content of the acetic acid was $32.5 \mu \mathrm{g} / \mathrm{mL}$ and prevailed over other acids. In the presence of calcium glycerophosphate as the sole source of carbon and phosphate nutrition, the concentration of butyric acid increased by $14.5 \mu \mathrm{g} / \mathrm{mL}$, valeric - by $17.0 \mu \mathrm{g} / \mathrm{mL}$, caproic - by $36.6 \mu \mathrm{g} / \mathrm{mL}$, caprylic - by $9.3 \mu \mathrm{g} / \mathrm{mL}$, and pelargonic - by $13.1 \mu \mathrm{g} / \mathrm{mL}$, compared with the previous variant. In the presence of $\mathrm{Ca}_{3}\left(\mathrm{PO}_{4}\right)_{2}$, B. subtilis IMV B-7023 produced the acetic and isobutyric acids. The concentrations of these compounds reached a maximum (300.0 and $90.0 \mu \mathrm{g} / \mathrm{mL})$ after 48 hours of cultivation of bacteria, and then decreased.
\end{abstract}

Keywords: Bacillus subtilis; organic acids; calcium glycerophosphate; calcium orthophosphate

\section{INTRODUCTION}

The world scientific community pays considerable attention to the development of new technologies of biopreparations, that based on use highly effective strains of bacteria that stimulate plant growth and development (plant growth promoting rhizobacteria, PGPR) (Van der Ent et al., 2009). Ecological compatibility of biologics contributes to their active introduction into agricultural practice.

One of the most promising objects in the industrial production of preparation for various fields of human activity, including plant growing, are bacteria of the genus Bacillus (Siddiqui, 2006). Compared to other artificially introduced into agrobiocenosis free-living microorganisms, their advantage lies in the ability to avoid competitive pressure on the part of aboriginal microflora (Maksimov et al., 2011).

Strain B. subtilis IMV B-7023 is a component of a highly effective complex bacterial preparation Azogran (Patent № 54923A). Bacterium synthesizes a complex of biologically active compounds (Skorochod et al., 2013; Tserkovniak et al., 2009a,b), whose components may affect plant growth and development (Roy et al., 2003), and provide protection against abiotic and biotic stress factors (Roy et al., 2005; Roy et al., 2012; Skorochod et al., 2011) Investigated bacilli are characterized by high activity in mobilization and mineralization of poorly soluble phosphorus $(\mathrm{P})$ compounds, which promotes the subsequent availability of this important macroelement to plants (Roy et al., 2004).

One of the dominant mechanisms responsible for the formation of available forms of $\mathrm{P}$ in soil are mobilized by organic acids (OA) synthesized by phosphate mobilizing microorganisms (Cheng et al., 2017; Rodríguez et al., 1999). These metabolites through their hydroxyl and carboxylic groups chelate the cations bound to phosphate and then make it available for the plant use (Sagoe $\boldsymbol{e t}$ al., 1998).

However, today there is insufficient information on the dependence of the synthesis of OA by bacilli on the source of their phosphate nutrition. Since identification of $\mathrm{OA}$ can be important in elucidating the formation of strategies by highly effective strains of bacteria in relation to their positive effects on plants. Accordingly, the purpose of the work was to investigate the synthesis of organic acids by the strain B. subtilis IMV B-7023 for its cultivation in nutrient media with organic and inorganic compounds phosphorus

\section{MATERIAL AND METHODS}

\section{Bacterial strains and nutrient media}

The object of the study was strain B. subtilis IMV B-7023, isolated from black soil (Cherkassy region, Ukraine). The strain is supported at the Depositary of the Zabolotny Institute of Microbiology and Virology, NAS of Ukraine (Patent № 54923A). The strain was cultivated in liquid nutrient media of the following composition:

I. glucose-mineral medium with organic source of phosphorous nutrition (Menkina, 1950), $(\mathrm{g} / \mathrm{L}):\left(\mathrm{NH}_{4}\right)_{2} \mathrm{SO}_{4}-0.5, \mathrm{MgSO}_{4} \cdot 7 \mathrm{H}_{2} \mathrm{O}-0.3, \mathrm{KCl}-0.3, \mathrm{CaCO}_{3}$ - 5.0, $\mathrm{MnSO}_{4} \cdot 7 \mathrm{H}_{2} \mathrm{O}-0.001, \mathrm{FeSO}_{4}-0.001$, glucose - 10.0, calcium glycerophosphate - $2.0(\mathrm{pH} 7.0-7.4)$;

II. modified mineral medium (Menkina, 1950), in which no glucose was added, and calcium glycerophosphate was the only source of carbon and phosphorus nutrition;

III. glucose-mineral medium with inorganic source of phosphorous nutrition (Muromtsev, 1957), (g/L): $\mathrm{MgSO}_{4} \cdot 7 \mathrm{H}_{2} \mathrm{O}-0.2 ; \mathrm{K}_{2} \mathrm{SO}_{4}-0.2$; $\left(\mathrm{NH}_{4}\right)_{2} \mathrm{SO}_{4}-0.5$; glucose - 10.0; $\mathrm{Ca}_{3}\left(\mathrm{PO}_{4}\right)_{2}-2.0$; yeast autolysate - 2.0; $\mathrm{pH} 6.5$ -7.0 .

All the reagents used were analytical grade and obtained from CHEMLABORREACTIV, Ltd. (Kyiv region, Ukraine). Chemicals were used as received without further treatment.

The strain B. subtilis IMV B-7023 was cultured under batch conditions with shaking at $240 \mathrm{rpm}$ in Erlenmeyer's flasks of $750 \mathrm{~mL}$ volume containing $100 \mathrm{~mL}$ of the corresponding nutrient medium. The growing time was $24-72$ hours at a temperature of $28 \pm 1^{\circ} \mathrm{C}$. The number of viable cells (colony-forming units (CFU)) was determined by the method of seeding a suspension of bacteria on an agar potato medium from serial ten-fold dilutions. 


\section{Obtaining of the culture medium of bacteria $B$. subtilis IMV B-7023}

The culture liquid of $B$. subtilis IMV B-7023 after completion of this strain growth was freed from the cells of bacterium by centrifugation on the centrifuge OPn-8 (joint stock company "TNK DASTAN," Kirgizstan) during $15 \mathrm{~min}$ at $5000 \mathrm{~g}$. In the obtained culture medium (CM) of B. subtilis IMV B-7023, the content of organic acids and concentration of $\mathrm{PO}_{4}{ }^{3-}$ were determined (Lurie, 1974).

\section{Chromatographic Analysis}

Qualitative and quantitative detection of organic acids was performed using a gas chromatograph with a mass spectrometric detector (GC-MS) manufactured by Agilent, model $6890 \mathrm{~N} / 5973$ inert equipped with the NIST02 mass-spectrums library used to identify the compounds (Center for Collective Use of Scientific Instruments of the NAS of Ukraine). The system is meant to be used in the modes of electron ionization and chemical ionization, thereby enabling to run highquality qualitative and quantitative analyses, determine the molecular weight of the reviewed objects and identification of unknown compounds. The concentration of organic acids was determined by the peak areas that were obtained for authentic standards.

\section{Statistical Analysis}

Microsoft Excel (Microsoft Corporation, USA) was used to analyze the data on the average of the three replicates $( \pm \mathrm{SE})$ obtained from the three independent experiments. Differences were compared with the statistical significance at a $\mathrm{P}$ level less than $0.05(\mathrm{P}<0.05)$. The Kolmogorov-Smirnov test was used to assess the normality of the distribution of each treatment (Lakin, 1990; Zar, 1984).

\section{RESULTS AND DISCUSSION}

Synthesis of organic acids by bacterium B. subtilis IMV B-7023 during its cultivation in a glucose-mineral medium with calcium glycerophosphate

Soil is a peculiar dynamic system that is an ecological niche of the biological activity of various organisms (Bagyaraj et al., 2000) the functioning of which is determined by the free flow of various micro and macro elements. Among them, an important place is given to phosphorus $(\mathrm{P})$. It is an integral component in ensuring the processes of growth and development of living organisms. However, due to the low availability of soluble minerals (apatite, hydroxyapatite) and organic (inositol phosphate, phosphoesters) forms of phosphorus in the soil, plants are limited in its assimilation (Gamalero et al., 2011; Vessey, 2003)

The solubilization of insoluble forms of $\mathrm{P}$ is an extremely important problem for increasing the consumption of this macroelement by crops (Alam et al., 2002; Nautiyal, 1999). Microorganisms are responsible for this process in soil, in particular bacteria, which make up about $50 \%$ of microbiota, capable of dissolving various forms of phosphorus (Khan et al., 2009). They form a peculiar group under the general name of phosphate-solubilizing bacteria (FSB), which include representatives of the genera Pseudomonas, Bacillus, Rhizobium Micrococcus, Flavobacterium, Burkholderia, Achromobacter, Erwinia and Agrobacterium (Rodríguez et al., 1999). A significant part of them function in the rhizosphere and is able to colonize the roots of plants, thus ensuring the growth and development of the latter. Therefore, these FSB are also known as plant growth promoting rhizobacteria (PGPR) (Hayat et al., 2010).

Initiators of transformation process of $\mathrm{P}_{\text {insoluble form }}$ to $\mathrm{P}_{\text {soluble form }}$ are low molecular organic acids, which are produced by phosphate-solubilizing bacteria (Chen $\boldsymbol{e t}$ al., 2006). According to the literature (Hinsinger, 2001; Plassard et al., 2010) $\mathrm{OA}$ are can promote mobilizing both mineral and organic phosphates, which release phosphate groups. However, there is little information about factors influencing the synthesis and the composition of OA which are produced by bacteria depending on the initial source of phosphorus. Such studies should be conducted with microorganisms, which are actively involved in mobilization, and mineralization of phosphorus containing compounds. Therefore, as the main object of experimental work, the strain B. subtilis IMV B-7023 was chosen (Roy et al., 2004). We found that at presence of organic compound of $\mathrm{P}$ - calcium glycerophosphate and glucose in the nutrient medium, the studied bacterium synthesized 9 organic acids after 24 hours of cultivation (Figure 1). Among them, in a quantitative index, acetic acid prevailed $-32.5 \mu \mathrm{g} / \mathrm{mL}$, which, along with isobutyric acid, was determined throughout the period of bacillus cultivation (Table 1). It was established that at $48 \mathrm{~h}$ of cultivation of the strain $B$. subtilis IMV B-7023 were produced, in addition to the two above-mentioned OA, valeric, enanthic, caprylic, pellargonic acids. At the same time, at 72 hours in the CM of investigated strain, most of the OA were not determined, except for acetic and isobutyric acids, which concentration dropped to 19.0 and $1.0 \mu \mathrm{g} / \mathrm{mL}$ respectively (Table 1 )

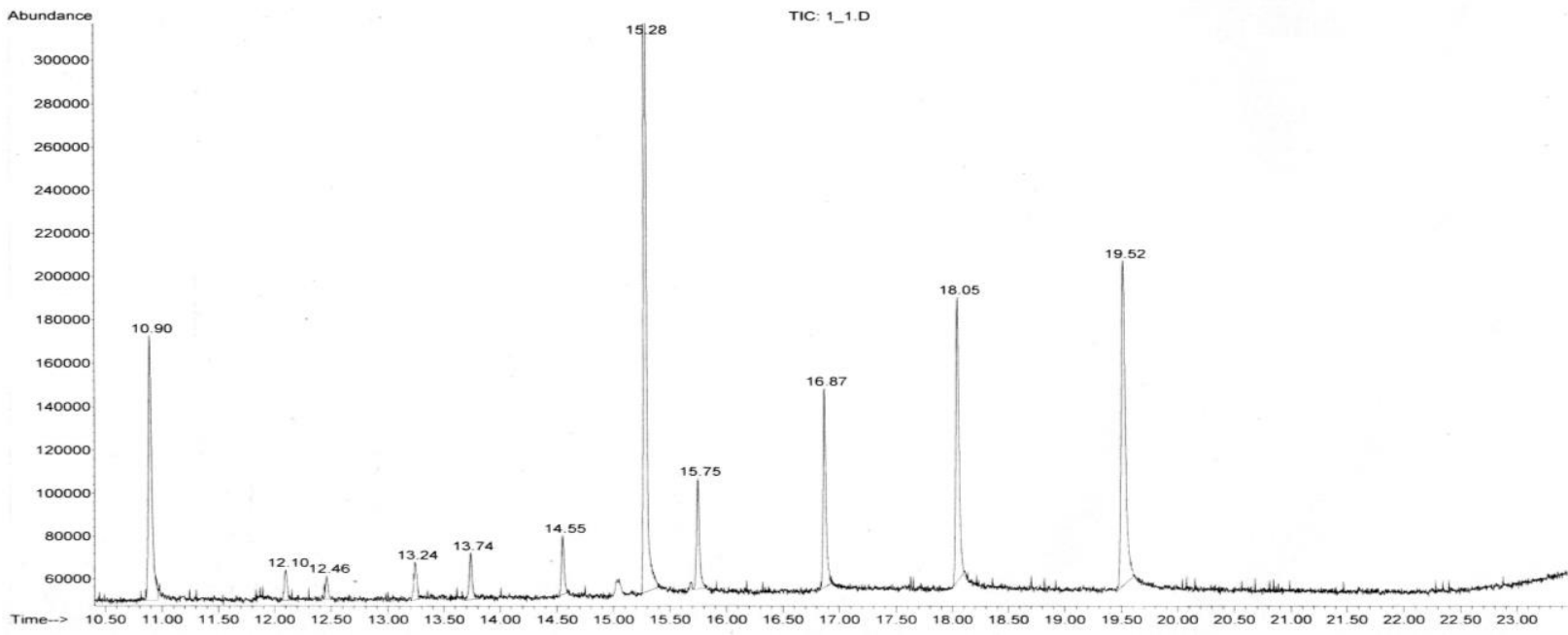

Figure 1 GC-MS spectra of organic acids CM of the bacterium Bacillus subtilis IMV B-7023 at its cultivation in a nutrient medium with glucose and calcium glycerophosphate

Table 1 The content of organic acids in the culture medium of the bacterium Bacillus subtilis IMV B-7023 at its cultivation in a glucose-mineral medium with calcium glycerophosphate

\begin{tabular}{llccc}
\hline \multirow{2}{*}{ RT, min } & Organic acid & \multicolumn{3}{c}{$\begin{array}{c}\text { Content OA }(\boldsymbol{\mu g} / \mathbf{m L}), \text { at cultivation of } \\
\text { bacterium for an, hours }\end{array}$} \\
\cline { 3 - 5 } & & $\mathbf{2 4}$ & $\mathbf{4 8}$ & $\mathbf{7 2}$ \\
10.90 & Acetic & $32.5 \pm 3.2$ & $15.0 \pm 1.1$ & $19.0 \pm 1.3$ \\
12.46 & Isobutyric & $5.5 \pm 0.4$ & $2.0 \pm 0.2$ & $1.0 \pm 0.1$ \\
13.24 & Butyric & $4.5 \pm 0.3$ & - & - \\
13.74 & Isovaleric & $2.0 \pm 0.2$ & - & - \\
14.55 & Valeric & $6.0 \pm 0.4$ & $2.0 \pm 0.2$ & - \\
15.75 & Caproic & $1.4 \pm 0.1$ & - & - \\
16.87 & Enanthic & $2.4 \pm 0.2$ & $2.0 \pm 0.2$ & - \\
18.04 & Caprylic & $3.7 \pm 0.3$ & $4.0 \pm 0.3$ & - \\
19.52 & Pelargonic & $5.9 \pm 0.4$ & $6.0 \pm 0.4$ & - \\
\hline
\end{tabular}

*: «-» - not identified.
Synthesis of organic acids by bacterium B. subtilis IMV B-7023 during its cultivation in a modified mineral medium with calcium glycerophosphate

It was shown that at cultivation of bacillus in a nutrient medium that did not contain glucose, and calcium glycerophosphate was the only source of carbon and phosphorus nutrition, the composition of carboxylic acids in CM of bacterium was almost identical to the previous version (Figure 2). However, the concentrations of most of them significantly differed and were much higher than when the investigated strain B. subtilis IMV B-7023 was cultured in a glucosemineral medium (Table 1 and 2). In particular, butyric acid - by $14.5 \mu \mathrm{g} / \mathrm{mL}$ valeric - by $17.0 \mu \mathrm{g} / \mathrm{mL}$, caproic - by $36.9 \mu \mathrm{g} / \mathrm{mL}$, caprylic - by $9.3 \mu \mathrm{g} / \mathrm{mL}$ and pelargonic - by $13.1 \mu \mathrm{g} / \mathrm{mL}$ (Table 1 and 2). An exception was that the content of acetic acid dropped 1.7 times (Table 1 and 2) and not was identified of isobutyric and isovaleric acids. At the same time at the cultivation of B. subtilis IMV B7023 in a medium where calcium glycerophosphate was the only source of phosphoric and carbon nutrition - the bacterium does not synthesized isomers of butyric and valeric acids. Carbohydrates can be substrate for the formation of some organic acids (acetic, propionic, butyric, valeric) (Fleming et al., 1986), at 
the same time isobutyric acid is derivate of valine and isovaleric acid - of leucine (Nakae $\boldsymbol{e t}$ al., 1965). In the synthesis of both amino acids, glucose is involved (Teresava et al., 1990; Tsuchida et al., 1986). Since modified medium does not contain this carbohydrate, valine and leucine may not be produced in sufficient a quantity that makes it impossible the synthesis of isoforms valeric and butyric acids.

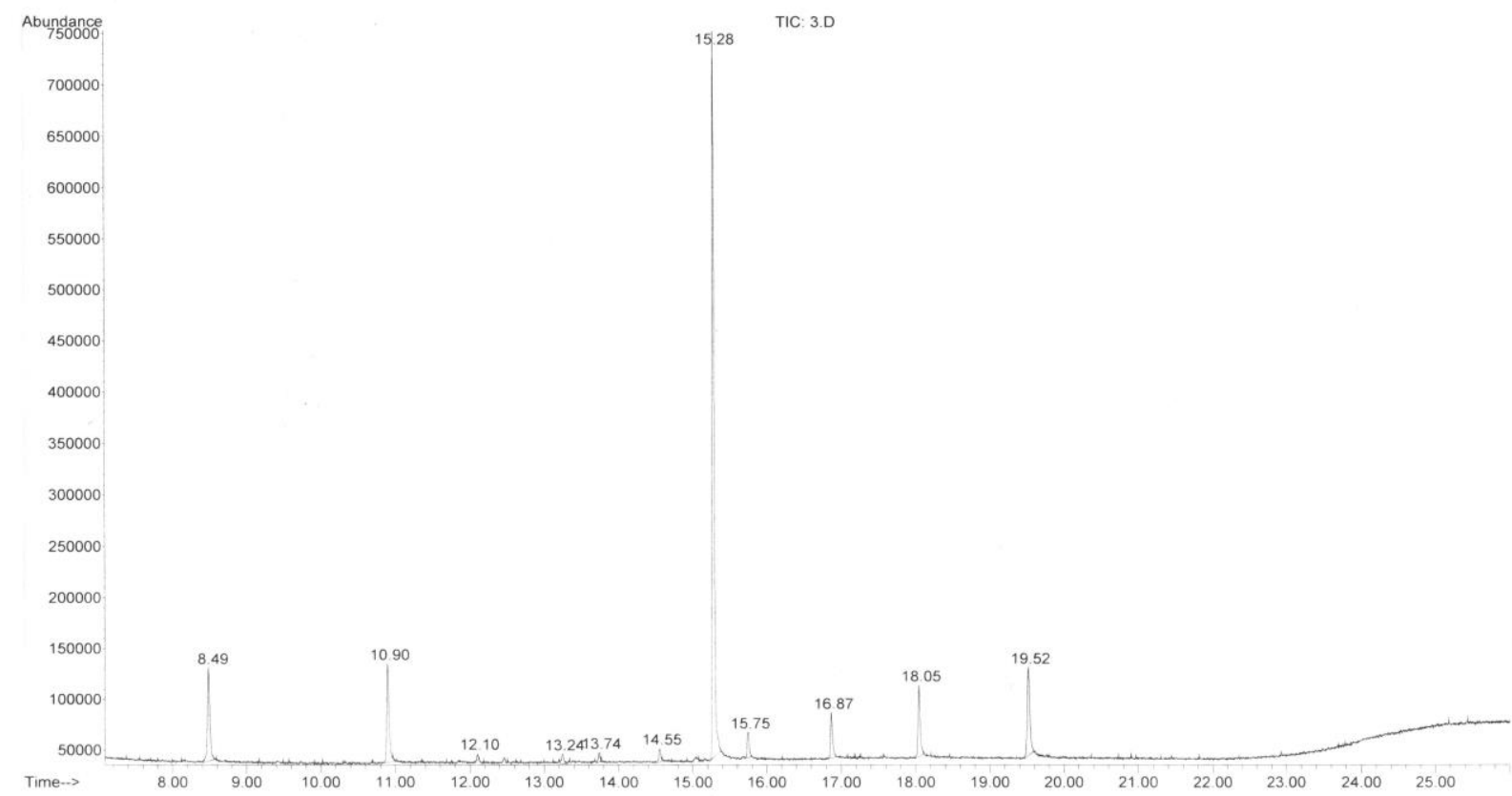

Figure 2 GC-MS spectra of organic acids CM of the bacterium Bacillus subtilis IMV B-7023 at its cultivation in a nutrient medium with calcium glycerophosphate

Table 2 The content of organic acids in the culture medium of the bacterium Bacillus subtilis IMV B-7023 during its cultivation in a mineral medium with calcium glycerophosphate and without glucose

\begin{tabular}{llccc}
\multirow{2}{*}{ RT, min } & Organic acid & \multicolumn{3}{c}{$\begin{array}{r}\text { Content OA }(\boldsymbol{\mu g} / \mathbf{m L}), \text { at cultivation of } \\
\text { bacteria for an, hours }\end{array}$} \\
\cline { 3 - 5 } & & $\mathbf{2 4}$ & $\mathbf{4 8}$ & $\mathbf{7 2}$ \\
10.90 & Acetic & $19.0 \pm 1.2$ & $15.0 \pm 1.1$ & $19.0 \pm 1.3$ \\
13.24 & Butyric & $19.0 \pm 1.3$ & - & - \\
14.55 & Valeric & $23.0 \pm 1.4$ & - & $0.7 \pm 0.05$ \\
15.75 & Caproic & $38.0 \pm 3.1$ & - & - \\
16.87 & Enanthic & $7.0 \pm 0.6$ & - & - \\
18.04 & Caprylic & $13.0 \pm 1.1$ & $1.0 \pm 0.1$ & - \\
19.52 & Pelargonic & $19.0 \pm 1.4$ & $2.0 \pm 0.2$ & - \\
$*:$ *-»- not identified. & & &
\end{tabular}

Synthesis of organic acids by bacterium $B$. subtilis IMV B-7023 at its cultivation in glucose-mineral medium with $\mathrm{Ca}_{3}\left(\mathrm{PO}_{4}\right)_{2}$
The qualitative and quantitative composition of $\mathrm{OA}$ in the culture medium of bacterium $B$. subtilis IMV B-7023 significantly differed at its cultivation in a nutrient medium with an inorganic phosphorus compound $-\mathrm{Ca}_{3}\left(\mathrm{PO}_{4}\right)_{2}$. Only acetic and isobutyric acids have been identified (Figure 3, Table 3). These compounds have been identified throughout the entire period of cultivation. The concentration of acetic acid was increased to $300 \mu \mathrm{g} / \mathrm{mL}$ after 48 hours of cultivation of $B$. subtilis IMV B-7023, while in the case of isobutyric practically not changed $(90.0 \mu \mathrm{g} / \mathrm{mL})$. However, after 72 hours, the content of both OA decreased slightly (Table 3 ). It should be noted that representatives of the genus Bacillus at their cultivation with calcium orthophosphate synthesize from 2 to 6 of OA (Chen et al., 2006; Zaidi et al., 2016).

In our studies with inorganic compound of $\mathrm{P}$, a decrease in the $\mathrm{pH}$ of the nutrien medium was observed, consistent with Sharma et al. (2012) and Mehta et al. (2015), which indicated that Ca-phosphate solubility increased with decreasing $\mathrm{pH}$. The decline of the latter indicates the production by rhizobacteria of organic acids that is obviously the main mechanism in the solubilization of mineral phosphates (Mehta et al., 2001).

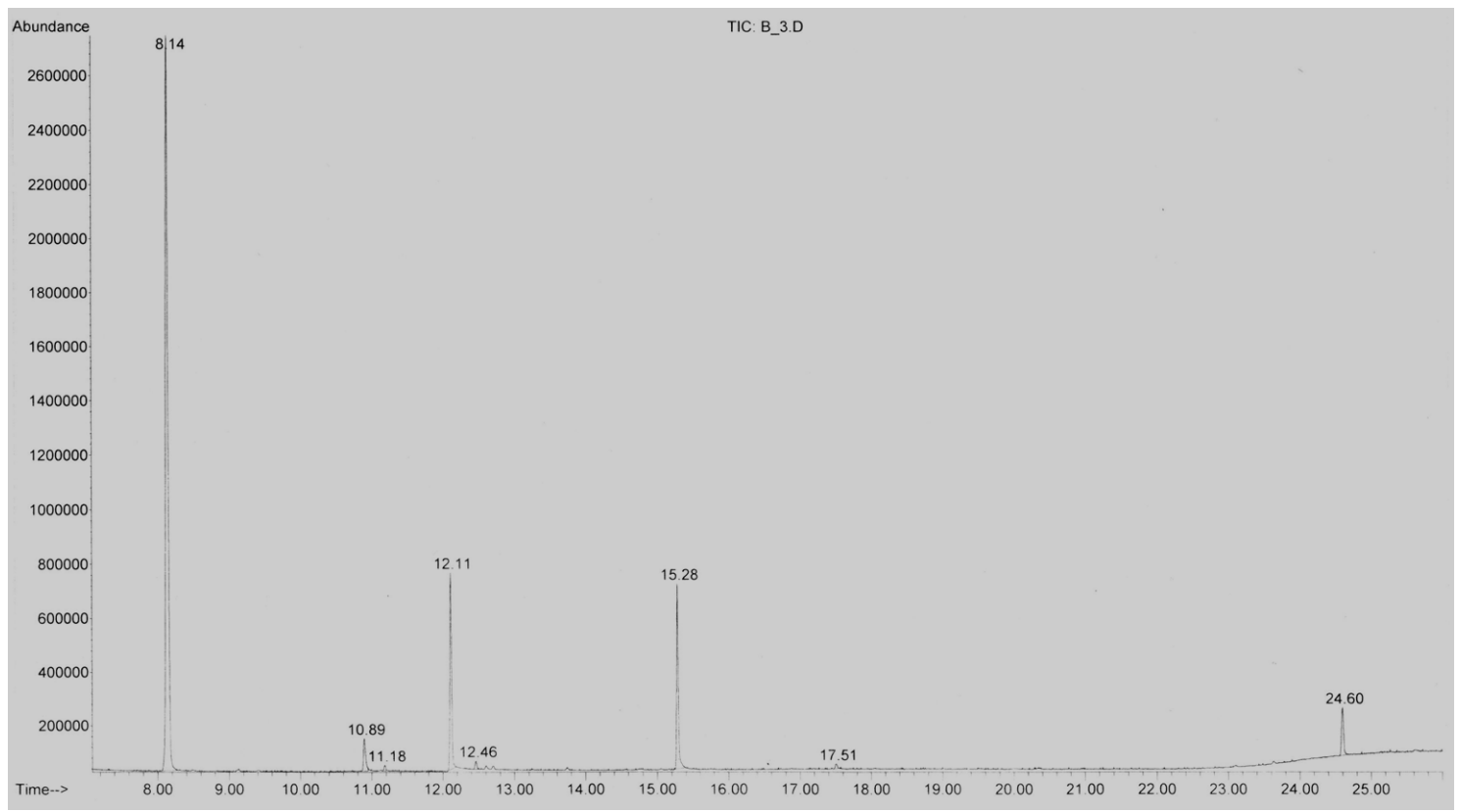

Figure 3 GC-MS spectra of organic acids in CM of the bacterium Bacillus subtilis IMV B-7023 during its cultivation in a nutrient medium with calcium orthophosphate 
Table 3 The content of organic acids in the culture medium of the bacterium Bacillus subtilis IMV B-7023 at its cultivation in a glucose-mineral medium with calcium orthophosphate $\left(\mathrm{Ca}_{3}\left(\mathrm{PO}_{4}\right)_{2}\right)$

\begin{tabular}{llccc}
\hline \multirow{2}{*}{ RT, min } & Organic acid & \multicolumn{3}{c}{$\begin{array}{c}\text { Content } \mathbf{~ O A ~}(\boldsymbol{\mu g} / \mathbf{m L}), \text { at cultivation of } \\
\text { bacterium for an, hours }\end{array}$} \\
\cline { 3 - 5 } & & $\mathbf{2 4}$ & $\mathbf{4 8}$ & $\mathbf{7 2}$ \\
10.89 & Acetic & $19.0 \pm 2.0$ & $300.0 \pm 40.0$ & $200.0 \pm 12.0$ \\
12.46 & Isobutyric & $92.0 \pm 8.0$ & $90.0 \pm 8.7$ & $80.0 \pm 7.6$ \\
\hline
\end{tabular}

Synthesis by bacillus of acetic and isobutyric acids at high concentrations was accompanied by a decrease in the $\mathrm{pH}$ of the nutrient medium from 6.7 to 4.3 , which caused a negative effect on growth activity. The amount of phosphate ions in the culture medium B. subtilis IMV B-7023 increased by almost 8 times after $48 \mathrm{~h}$ cultivation (Table 4 ).

Table 4 Physiological activity of Bacillus subtilis IMB B-7023 at cultivation in a nutrient medium with $\mathrm{Ca}_{3}\left(\mathrm{PO}_{4}\right)_{2}$

\begin{tabular}{lccc}
\hline $\begin{array}{l}\text { Term of } \\
\text { cultivation, } \\
\text { hours }\end{array}$ & $\mathbf{p H}$ & $\begin{array}{c}\text { Number of viable cells } \\
\text { (CFU/mL) }\end{array}$ & $\mathbf{P O}_{\mathbf{4}}^{\mathbf{- 3}, \mathbf{m g} / \mathbf{L}}$ \\
\hline 0 & 6.7 & $(6,5 \pm 0,1) \cdot 10^{7}$ & $66,0 \pm 5,7$ \\
24 & 4.7 & $(1,3 \pm 0,1) \cdot 10^{9}$ & $376,7 \pm 23,6$ \\
48 & 4.5 & $(1,4 \pm 0,1) \cdot 10^{7}$ & $446,7 \pm 9,8$ \\
72 & 4.3 & $(2,1 \pm 0,2) \cdot 10^{6}$ & $433,3 \pm 16,8$ \\
\hline
\end{tabular}

\section{CONCLUSION}

Thus, the quantitative and qualitative composition of organic acids synthesized by strain B. subtilis IMV B-7023 depended on the composition of the nutrien medium. The largest number of OA differing in structure of the $\mathrm{C}-\mathrm{C}$ chain were identified in the culture medium of bacillus cultured in the classical glucosemineral medium (with glucose and an organic compound of phosphorus calcium glycerophosphate) or in its modified form (with calcium glycerophosphate but without glucose). The $B$. subtilis IMV B-7023 at cultivation with inorganic compound of $\mathrm{P}-\mathrm{Ca}_{3}\left(\mathrm{PO}_{4}\right)_{2}$ synthesized only acetic and isobutyric acids, whose concentrations were at times higher than in medium with calcium glycerophosphate.

\section{REFERENCES}

ALAM, S., KHALIL, S., NAJMA, A., RASHID, M. 2002. In vitro solubilization of inorganic phosphate by phosphate solubilizing microorganisms (PSM) from maize rhizosphere. International Journal of Agriculture and Biology, 4(4), 454458

BAGYARAJ, D.J., KRISNARAJ, P.U., KHANUJA, S.P.S. 2000. Mineral phosphate solubilization: agronomic implication, mechanism and molecular genetics. Proceedings of the Indian National Science Academy. Part B, Reviews and Tracts - Biological Sciences, 66 (2/3), 69-82.

CHENG, J., ZHUANG, W., LI N.N., TANG C.L., YING H.J. 2017. Efficient biosynthesis of d-ribose using a novel co-feeding strategy in Bacillus subtilis without acid formation. Letters Applied Microbiology, 64, 73-78. https://doi.org/10.1111/lam.12685

CHEN, Y.P., REKHA, P.D., ARUN, A.B., SHEN, F.T., LAI, W.A., YOUNG C.C. 2006. Phosphate solubilizing bacteria from subtropical soil and their tricalcium phosphate solubilizing abilities. Applied Soil Ecology, 34, 33-41. https://doi.org/10.1016/j.apsoil.2005.12.002

FLEMING, S.E., ARCE, D.S. 1986. Volatile fatty acids: their production, absorption, utilization, and roles in human health. Clinics in Gastroenterology, 15(4), 787-814.

GAMALERO, E., GLICK, B.R. 2011. Mechanisms used by plant growthpromoting bacteria. In: Maheshwari D.K. (ed.), Bacteria in Agrobiology: Plant Nutrient Management. Berlin: Springer-Verlag, Heidelberg, pp 17-46. https://doi 10.1007/978-3-642-21061-7 2; ISBN: 978-3-642-21060-0.

HAYAT, R., ALI, S., AMARA, U., AHMED, I. 2010. Soil beneficial bacteria and their role in plant growth promotion: a review. Annals of Microbiology, 60(4), 579-598. https://doi.org/10.1007/s13213-010-0117-1

HINSINGER, P. 2001. Bioavailability of soil inorganic P in the rhizosphere as affected by root-induced chemical changes: a review. Plant and Soil, 237(2), 173-195. https://doi.org/10.1023/A:1013351617532

KHAN, A.A., JILANI, G., AKHTAR, M.S., NAQVI, S.M.S., RASHEED M. 2009. Phosphorus solubilizing bacteria: occurrence, mechanisms and their role in crop production. Journal of Agriculture and Biological Sciences, 1(1), 48-58.

LAKIN, G.F. 1990. Biometrics. Moscow: Higher School, 352 p. ISBN: 5-06000471-6

LURIE, Yu.Yu. 1974. Analytical chemistry of industrial wastewater. Moscow: Chemistry, $448 \mathrm{p}$.

MAKSIMOV, I.V., ABIZGIL'DINA, R.R., PUSENKOVA, L.I. 2011. Plan growth promoting rhizobacteria as alternative to chemical crop protectors from pathogens (review). Applied Biochemistry and Microbiology, 47(4), 337-385. https://doi.org/10.1134/S0003683811040090
MEHTA, S., NAUTIYAL, C.S. 2001. An efficient method for qualitative screening of phosphate-solubilizing bacteria. Current Microbiology, 43(1), 5156. https://doi.org/10.1007/s002840010259

MEHTA, P., WALIA, A., KULSHRESTHA, S., CHAUHAN, A., SHIRKOT, C.K. 2015. Efficiency of plant growth-promoting P-solubilizing Bacillus circulans CB7 for enhancement of tomato growth under net house conditions. Journal of Basic Microbiology, 55(1), 33-44. https://doi.org/10.1002/jobm.201300562

MENKINA, R.A. 1950 Bacteria which mineralize organic phosphorus compounds. Microbiology, 19(4), 308-315.

MUROMTSEV, G.S. 1957. Methods for studying the dissolution of calcium phosphates by microorganisms. Microbiology, 26(2), 172-178.

NAKAE, T., ELLIOTT, J.A. 1965. Production of volatile fatty acids by some lactic acid bacteria. II. Selective formation of volatile fatty acids by degradation of amino acids. Journal of Dairy Science, 48(3), 293-299. https://doi.org/10.3168/jds.S0022-0302(65)88219-4

NAUTIYAL, C.S. 1999. An efficient microbiological growth medium for screening phosphate solubilizing microorganisms. FEMS Microbiology Letters, 170, 265-270. https://doi.org/10.1111/j.1574-6968.1999.tb13383.x

PATENT of Ukraine № 54923A. Strain of bacteria Bacillus subtilis for bacterial fertilizer obtaining for plant-growing / I. K.Kurdish, A. O. Roy. - Published in 2003, bulletin № 3 (in Ukraine).

PLASSARD, C., DELL, B. 2010. Phosphorus nutrition of mycorrhizal trees. Tree Physiology, 30(9), 1129-1139. https://doi.org/10.1093/treephys/tpq063

RODRÍGUEZ, H., FRAGA, R. 1999. Phosphate solubilizing bacteria and their role in plant growth promotion. Biotechnology Advances, 17(4-5), 319-339. https://doi.org/10.1016/s0734-9750(99)00014-2

ROY, A.A., CHERNOVA, L.S., KURDISH, I. K. 2003. The influence of metabolic products of Bacillus subtilis IMV B-7023 on seed germination and plant development. Regulation of plant growth, development and productivity. (Proceeding of the 3th International Conference). Minsk, 116-117.

ROY, A.A., REVA, O.N., KURDISH, I. K., SMIRNOV, V.V., 2004. Biological properties of the phosphate-mobilizing Bacillus subtilis strain IMV B-7023. Applied Biochemistry and Microbiology, 40(5), 551-557. https://doi.org/10.1023/B:ABIM.0000040671.26369.19

ROY, A.A., ZALOILO, O.V., CHERNOVA, L.S., KURDISH, I. K. 2005 Antagonistic activity of phosphate-mobilizing bacilli to phytopathogenic fungi and bacteria. Agroecological Journal, 1, 50-55.

ROY, A.A., PASICHNYK, L.A., TSERKOVNIAK, L. S., KHODOS, S.F. KURDISH, I. K. 2012. Influence of bacteria of Bacillus genus on the agent of bacterial cancer of tomatoes. Microbiology Journal, 74(5), 74-80.

SAGOE, C.I., ANDO, T., KOUNO, K., NAGAOKA, T. 1998. Relative importance of protons and solution calcium concentration in phosphate rock dissolution by organic acids. Soil Science and Plant Nutrition 44(4), 617-625 https://doi.org/10.1080/00380768.1998.10414485

SHARMA, B.C., SUBBA, R., SAHA, A. 2012. In vitro solubilization of tricalcium phosphate and production of IAA by phosphate solubilizing bacteria isolated from tea rhizosphere of Darjeeling Himalaya. Plant Sciences Feed, 2(6), 96-99.

SIDDIQUI, Z.A. 2006. PGPR: Prospective biocontrol agents of plant pathogens. In: Siddiqui, Z.A. (ed.) PGPR: Biocontrol and Biofertilization. Netherlands: Dordrecht, Springer, pp 111-142. ISBN: 978-1-4020-4152-5.

SKOROCHOD, I.O., TSERKOVNIAK, L. S., KURDISH, I. K. 2011. The antioxidant effect of Bacillus subtilis and Azotobacter vinelandii on the seeds of cereals. Microbiology Journal, 73(1), 44-50.

SKOROCHOD, I.A., ROY, A.O., MELIENTIEV, A.I., KURDISH, I. K. 2013. Influence of bioactive substances phosphate-mineralizing strains genus Bacillus on plants seeds affected by oxidative stress. Microbiology \& Biotechnology, 2, 41-45.

TERESAVA, M., INUI, M., GOTO, M., SHIKATA, K., IMANARI, M., YUKAWA, H. 1990. Living cell reaction process for L-isoleucine and L-valine production. Journal of Industrial Microbiology, 5(5), 289-293. https://doi.org/10.1007/BF01578203

TSERKOVNIAK, L. S., KURDISH, I. K. 2009a. Phosphate-mobilizing bacteria Bacillus subtilis as phenolic producers. Applied Biochemistry and Microbiology, 45(3), 279-284. http://dx.doi.org/10.1134/S0003683809030077

TSERKOVNIAK, L. S., ROY, A.O., KURDISH, I.K. 2009b. Synthesis of amino acids of Bacillus subtilis IMV B-7023 in the medium with calcium glycerophosphate. Microbiology Journal, 71(5), 18-23.

TSUCHIDA, T., MOMOSE, H. 1986. Improvement on an L-leucine-producing mutant of Brevibacterium lactofermentum 2256 by genetically desensitizing it to $\alpha$-acetohydroxy acid synthetase. Applied and Environmental Microbiology, 51(5), 1024-1027.

VAN der ENT, S., van WEES, S.C.M., PIETERSE, C.M.J. 2009. Jasmonate signaling in plant interactions with resistance inducing beneficial microbes. Phytochemistry, 70, https://doi.org/10.1016/j.phytochem.2009.06.009

VESSEY, J.K. 2003. Plant growth promoting rhizobacteria as biofertilizers. Plant and Soil, 255(2), 571-586. https://doi.org/10.1023/A:1026037216893 
ZAR, J. H. 1984. Biostatistical Analysis. Englewood Cliffs, NJ: Prentice-Hall, $718 \mathrm{p}$.

ZAIDI, A., KHAN, M.S., AHMAD, E., SAIF, S., RIZVI, A., SHAHID, M. 2016.

Growth stimulation and management of diseases of ornamental plants using phosphate solubilizing microorganisms: current perspective. Acta Physiologiae Plantarum, 38(5), 117. https://doi.org/10.1007/s11738-016-2133-7 